\title{
Standartlaştırılmış Yağış İndeksi Yöntemi Kullanılarak Salda Gölü Havzası Kuraklık Analizi Üzerine Bir Araştırma
}

\author{
Anıl EVCi ${ }^{1 *}$, Candan KUŞ ŞAHIN ${ }^{\text {ID } 1}$ \\ ${ }^{1}$ Süleyman Demirel Üniversitesi, Mimarlık Fakültesi, Isparta \\ Geliş Tarihi (Received): 18.05.2021, Kabul Tarihi (Accepted): 02.09.2021 \\ $\square$ Sorumlu Yazar (Corresponding author*): anilevci@sdu.edu.tr

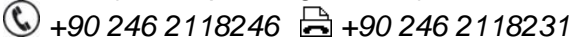

ÖZ

Kuraklık bir toplumun ekonomik yapısını, sosyokültürel özelliklerini ve ekolojik yapısını etkileyen önemli bir olaydır. Yaşanan kuraklıklar sonucunda; nehirlerin ve akarsu yataklarının kuruması veya akımlarının zarara uğraması, bitkiler üzerinde baskıların artması, tarımsal verimliliğin ve doğal yaşam aktivitelerinin azalması, göçlerin artması vb. tehlikeli durumlar kaçınılmazdır. Bu olumsuz etkileri kuraklığın belirli boyuttaki tahminleriyle en aza indirmek mümkündür. Kuraklığın alansal ve zamansal özellikleri ile şiddetini tanımlamak için kullanılan birçok yöntem bulunmaktadır. Bu yöntemlerden en fazla tercih edileni "Standartlaştırılmış Yağış İndeksi (SYi)" yöntemidir. Bu çalışmada, Standartlaştırılmış Yağış İndeksi yöntemi kullanılarak Salda Gölü Havzası için kuraklık analizi yapılmıştır. SYi değerleri, 1-3-6-12-24 aylık zaman periyotlarında, Yeşilova meteoroloji istasyonu verilerine göre hesaplanmıştır. Yapılan analiz sonuçlarına göre; alanda en şiddetli ve en uzun süreli kuraklıklar 1989-1995 yılları arasında gözlemlenmiştir. Son 10 yılda yaşanan kuraklıklar değerlendirildiğinde ise alanda her zaman normale yakın kuraklığın olabileceği öngörülmektedir.

Anahtar Kelimeler: Kuraklık, kuraklık analizi, Salda Gölü, standartlaştırılmış yağış indeksi

\section{A Study on the Drought Analysis of the Salda Lake Basin Using the Standardized Precipitation Index Method}

\begin{abstract}
Drought is an important event affecting the economic structure, sociocultural characteristics and ecological structure of a society. As a result of droughts dangerous situations are inevitable such as; drying of rivers and stream beds or damage to their flows, increased pressure on plants, decreased agricultural productivity and natural life activities, increased migration. It is possible to minimize these negative effects with certain size estimates of the drought. There are many methods used to describe the spatial and temporal characteristics and severity of drought. The most preferred of these methods is the "Standardized Precipitation Index (SPI). In the study, drought analysis was made for Salda Lake Basin using the Standardized Precipitation Index method. SPI values were calculated according to the data of Yesilova meteorology station in "1-3-6-12-24" month time periods. According to the results of the analysis, the most severe and longest droughts were observed between "1989-1995". When the droughts experienced in the last 10 years are evaluated, it is predicted that there may always be a drought close to normal in the area.
\end{abstract}

Keywords: Drought, drought analysis, Salda Lake, standardized precipitation index 


\section{GíRiş}

Küresel ısınma sonucunda iklimsel değişimler, sıcaklık seviyelerini ve yağış rejimlerini olumsuz seviyede etkilemektedir. Bunun sonucu olarak kuraklık, kaçınılmaz bir hal almaktadır. Kuraklık, meteorolojik kökenli en tehlikeli doğal afetlerden birisi olarak sayılmaktadır. Hangi seviyede olursa olsun kuraklığın şiddeti ve süresi üzerinde hassasiyetle durulması gerekmektedir. Çünkü kuraklığın etkisel boyutu, tüm ekosistemleri ve ekosistemler üzerinde yaşayan tüm canlıları uzun vadede olumsuz yönde etkileyebilmektedir.

Kuraklık; yağışların, normal seviyelerinden alta düşmesi sonucunda, doğal kaynakların etkilenmesine ve hidrolojik dengenin bozulmasına yol açan olay olarak tanımlanmaktadır. Kuraklığın nitelikleri; frekans, şiddet, süre ve etki alanı durumlarına göre sıralanabilmektedir. En önemli özellikleri ise; başlangıç ve bitişinin belirsiz oluşu, kümülatif olarak artması, aynı anda birden fazla kaynağa etkisi ve ekonomik boyutunun yüksek olmasıdır (MGM, 2021). Kuraklık, canlıların yaşamına etki eden, can ve mal kayıplarına yol açan diğer doğal afetlerden farklıdır. Çünkü kuvvetini yavaş yavaş artırmakta ve etkisi uzun süreli olmaktadır (Şaylan ve ark., 1997). Kuraklığa etki eden faktörler arasında; atmosferik koşullar, fiziki coğrafya faktörleri ve iklim koşulları yer almaktadır (MGM, 2021).

Kuraklık; meteorolojik kuraklık, hidrolojik kuraklık ve tarımsal kuraklık olmak üzere 3 türdür (Wilhite ve Glantz, 1987). Meteorolojik kuraklık; belirli bir zaman periyoduna ait normal düzeylerden (genellikle en az 30 yıllık) meydana gelen sapma olarak tanımlanmaktadır. Nem azlığının derecesi ve uzunluğu, meteorolojik kuraklığı belirlemekte ve bölgesel gelişimde farklılıklar göstermektedir (Kapluhan, 2013). Hidrolojik kuraklık; uzun süreli yağış eksikliği sonucunda ortaya çıkan, yeryüzü ve yeraltı sularındaki azalma ve eksiklikleri ifade etmektedir (MGM, 2021). Akarsu havzasında yağışlarda meydana gelecek değişim, doğrudan akarsu akımlarını da etkilemektedir (Yürekli ve ark., 2009). Yağmur eksikliği ile akarsu, dere ve rezervuarlardaki su eksikliği arasında bir zaman aralığı olduğundan, hidrolojik ölçümler kuraklığın ilk göstergelerinden birisi değildir. Meteorolojik kuraklık sona erdikten uzun bir süre sonra dahi hidrolojik kuraklık varlığını sürdürebilmektedir (MGM, 2021). Tarımsal kuraklık ise; toprak nemindeki azalma sonucu, bundan etkilenen tarımsal ürünlerdeki azalmaya bağlı olarak ortaya çıkan durumdur (Dracup ve ark., 1980). Tarımsal kuraklık, meteorolojik kuraklıktan sonra ve hidrolojik kuraklıktan önce meydana gelmektedir. Tarımsal kuraklık, toprağın derinlikleri doymuş halde olsa dahi ürün verimlerini ciddi oranda düşürebilmektedir. (MGM, 2021).
Ülkemizde, ulusal mevzuat ve uluslararası sözleşmelerle koruma altında bulunan alanların birçoğu kuraklık riski nedeniyle baskı altındadır. Burdur ilinin Yeşilova ilçesinde bulunan ve Özel Çevre Koruma Bölgesi statüsünde yer alan Salda Gölü Havzası da baskı altında bulunan korunan alanlardan bir tanesidir. Turkuaz renkli suyu ve beyaz kumuyla dünyada benzerine az rastlanan bir güzelliğe sahip olan Salda Gölü, son yıllarda yaşanan küresel ölçekteki kuraklıktan etkilenmiştir. Son 10 yılda Salda Gölü'nde 30-40 metre arasında çekilme olması bunun en büyük kanıtıdır. Havzadaki düzensiz yağış rejimleri, yoğun ve bilinçsiz bir şekilde sürdürülen tarımsal faaliyetler, şahıs ve kurumlar tarafından kullanılan sondaj kuyuları, Salda Gölü'nü besleyen dere ve yataklar üzerine kurulan sulama göletleri gibi faktörler havzanın yer altı ve yer üstü suyu rezervini olumsuz etkilemekte ve dolayısıyla bölgedeki kuraklığı artırmaktadır. Yapılan çalışmada, bahsedilen faktörler göz önünde bulundurularak, Salda Gölü Havzası'ndaki mevcut kuraklık durumunu ortaya koymak ve kuraklığın etkilerinin en aza indirilmesine yönelik alınması gereken stratejik önlem hedeflerini belirlemek amacıyla kuraklık analizi yapıımıştır.

Bir bölgedeki kuraklığın alansal ve zamansal özelliklerini, şiddetini tanımlamak için birçok kuraklık analizi yöntemi mevcuttur. Bu yöntemler içinde en fazla kullanılanı "Standartlaştırılmış Yağış İndeksi (SYi)" yöntemidir. Bu yöntemin yaygın olarak kullanılma sebebi, parametre olarak sadece yağış verilerinin yeterli olması, net sonuçların elde edilebilmesi ve farklı ölçeklerde yapılan değerlendirmelerin birbiriyle kıyaslanabilmesidir. Bu bağlamda Salda Gölü Havzası için Burdur Yeşilova meteoroloji istasyonundan alınan aylık toplam yağış değerleri kullanılarak 1-3-6-12 ve 24 aylık SYI kuraklık indis değerleri hesaplanmıştır. Böylece bölgedeki kuraklık durumu belirlenerek kuraklığın zamansal değişimi araştırılmıştır.

\section{MATERYAL VE YÖNTEM}

\section{Materyal}

Çalışmanın materyalini, Salda Gölü Havzası oluşturmaktadır. $37^{\circ} 29^{\prime}-37^{\circ} 33^{\prime}$ kuzey enlemi ile $29^{\circ} 37^{\prime}-$ $29^{\circ} 41^{\prime}$ doğu boylamı arasında kalan Salda Gölü; Ege Bölgesi, İç Anadolu Bölgesi ve Akdeniz Bölgesi arasında bulunmakta ve Güneybatı Anadolu'nun, Göller Bölgesi olarak adlandırılan alanda yer almaktadır (Kesici ve ark., 2018; TMMOB, 2020). Burdur ilinin en eski yerleşim yeri olan Yeşilova ilçesine bağlı olan Salda Gölü ilçe merkezine 4 km uzaklıktadır (Şekil 1). 


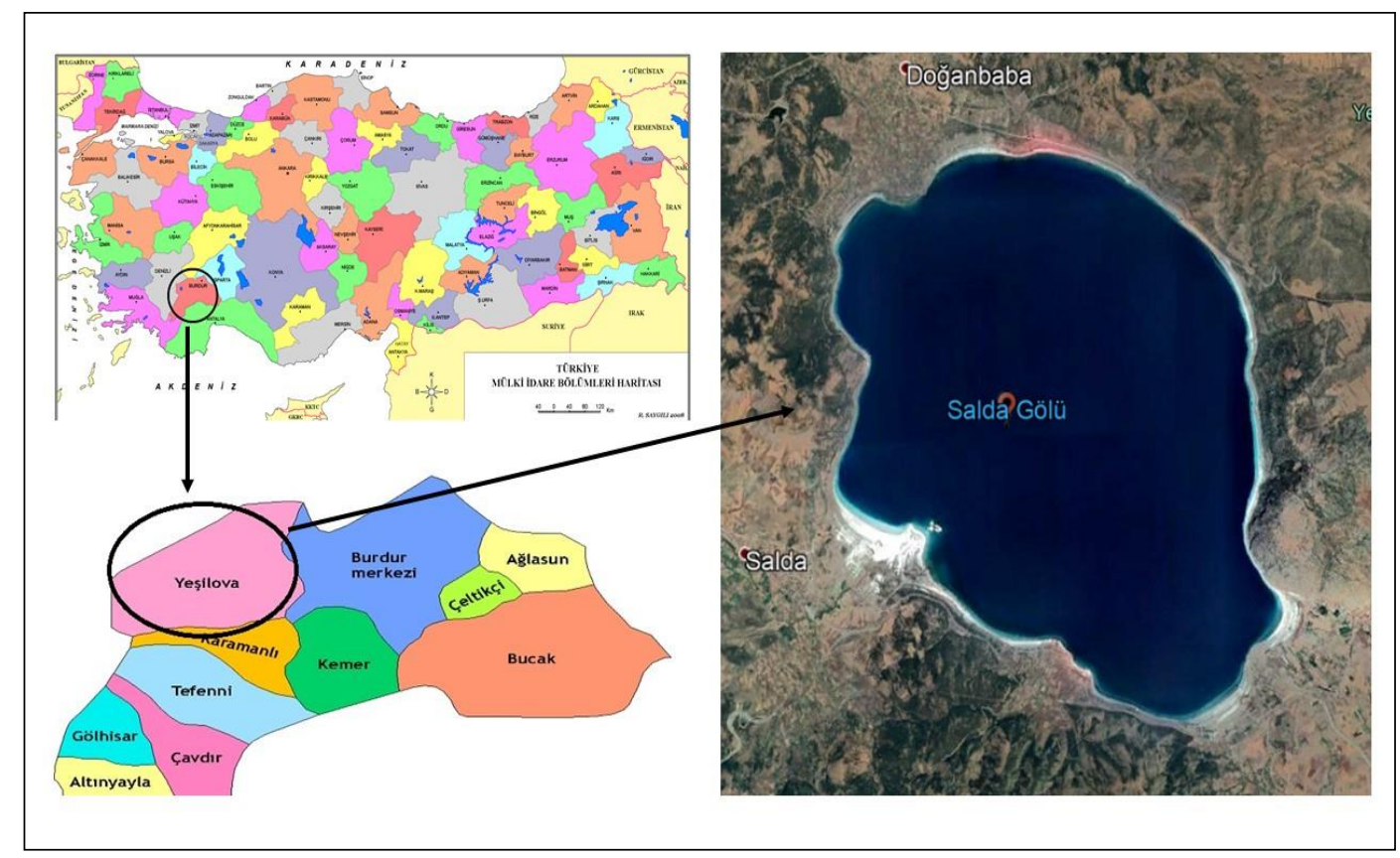

Şekil 1. Salda Gölü Havzası'nın konumu

Salda Gölü, Burdur Gölü havzası sınırları içerisinde yer almakta ve dışa akışı olmayan kapalı bir havza konumundadır. Ormanlık alanlarla kaplı tepeler, kayalık araziler ve küçük alüvyal ovalarla karstik, doğal konumda bulunan gölün deniz seviyesinden yüksekliği 1193 m'dir. $44 \mathrm{~km}^{2}$ lik bir alanı kaplayan göl, yaklaşık $6.8 \mathrm{~km}$ eninde, $9.186 \mathrm{~km}$ uzunluğunda, tektonik bir çukurun üzerine yerleşmiş kapalı bir çöküntü havzasında oluşmuş bir sulak alandır. Salda Gölü kapalı havzasının toplam büyüklüğü
214 km2 dir. Türkiye'nin en derin gölü olan Salda Gölü'nün derinliği 184 m'dir. Havza sınırları kuzeyde Doğanbaba köyüne, batıda Salda köyüne, güneydoğuda Kayadibi mahallesine, Yeşilova ilçesi merkezine ve Niyazlar köyüne kadar uzanmaktadır (Şekil 2) (Orman ve Su İşleri Bakanlığı, 2013; Kesici ve ark., 2018; Çevre ve Şehircilik Bakanlığı, 2021). 


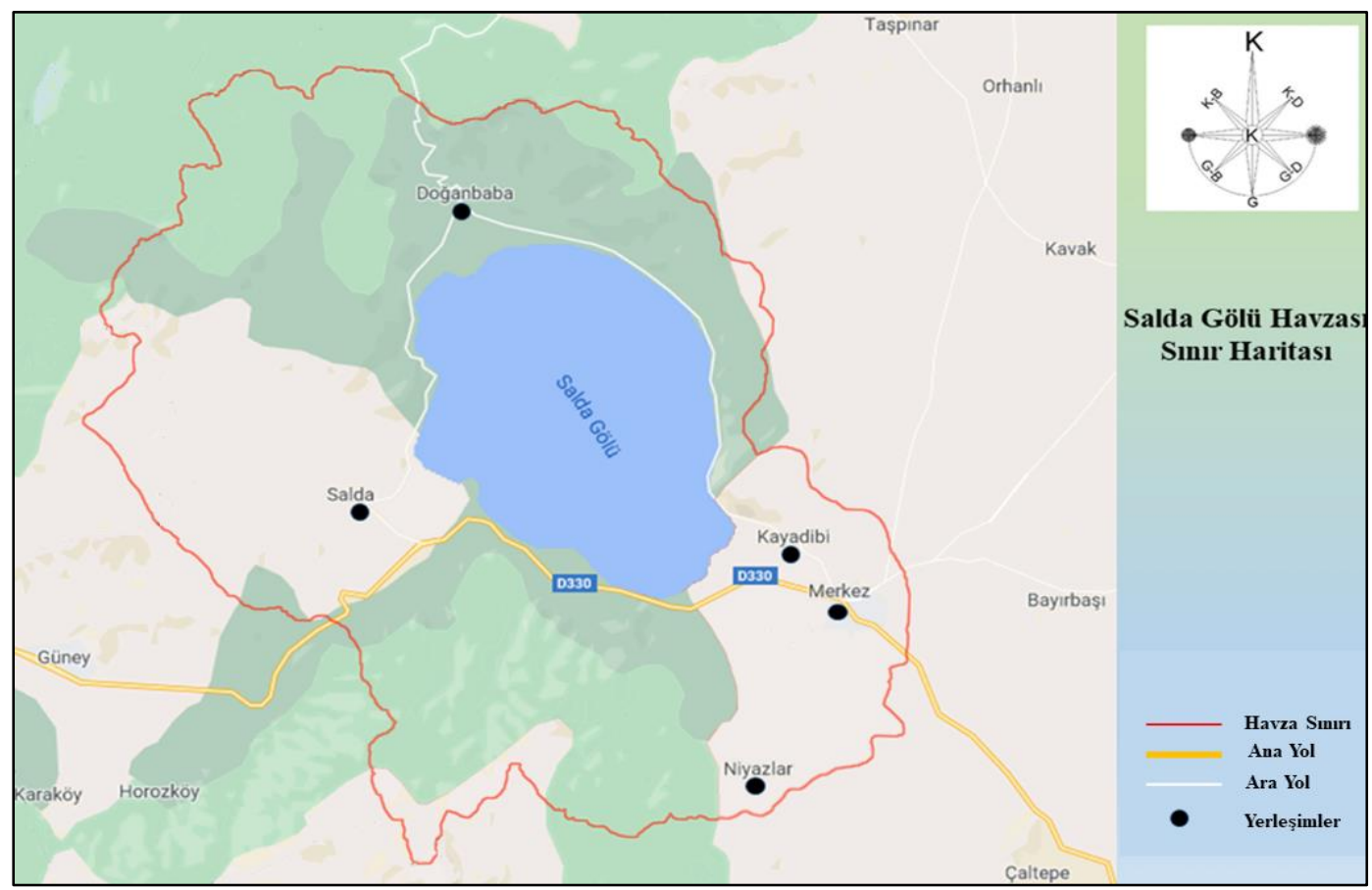

Şekil 2. Salda Gölü Havzası sınır haritası

11 Temmuz 2011 tarihinde havza içerisinde mesire alanı olarak kullanılan 120 dekarlık alan, "Tabiat Parkı" olarak ilan edilmiştir. 2019 yılı sınır değişikliği ile Tabiat Parkı büyüklüğü 540 dekara çıkartılmıştır (Kültür ve Turizm Bakanlığı, 2021). Salda Gölü, sosyokültürel yaşam bütünlügünü koruyabilmiş, peyzaj özellikleri bakımından IUCN tarafından koruma altına alınmış endemik ve nesli tehlike altındaki türlerin barınma, beslenme ve üreme gibi hayati gereksinimlerini karşılayabileceği uygun yaşama şartlarına sahip bir sulak alan olmasından dolayı 14.03.2019 tarih ve 824 sayılı Cumhurbaşkanı Kararı ile 295,63 km²'lik alan "Özel Çevre Koruma Bölgesi" (ÖÇKB) olarak tespit ve ilan edilmiştir (Çevre ve Şehircilik Bakanlığı, 2021).

Salda Gölü ve çevresi iklim bakımından Burdur Havzası iklimiyle benzer özellikler göstermektedir. Akdeniz iklimi ile İç Anadolu iklimi arasında bir geçiş bölgesi durumunda bulunan bölgede, yoğun olarak İç Anadolu iklimi hüküm sürmektedir. Kışlar soğuk ve yağışlı, yazlar ise sıcak ve kurak geçmektedir. MGM verilerinden elde edilerek üretilen Salda Gölü Havzası uzun dönem (19812019 yılları arası) yıllık ortalama yağış değerleri Şekil 3'te verilmiştir.

Havzadaki yıllık ortalama yağış değerleri incelendiğinde, havzada düzensiz yağış rejimi olduğu görülmektedir. 39 yıllık ortalama yağış değeri $488,1 \mathrm{~mm}$ iken, en fazla yağış alan yıl ortalama 741,2 mm ile 2009 yılı ve en az yağışın olduğu yıl ortalama 303,1 mm ile 1989 yılıdır. Şekil incelendiğinde; 39 yıllık sürenin 21 yılında, ortalama yağışlar genel yağış ortalamasının altında iken 18 yılında ortalamanın üzerindedir. 


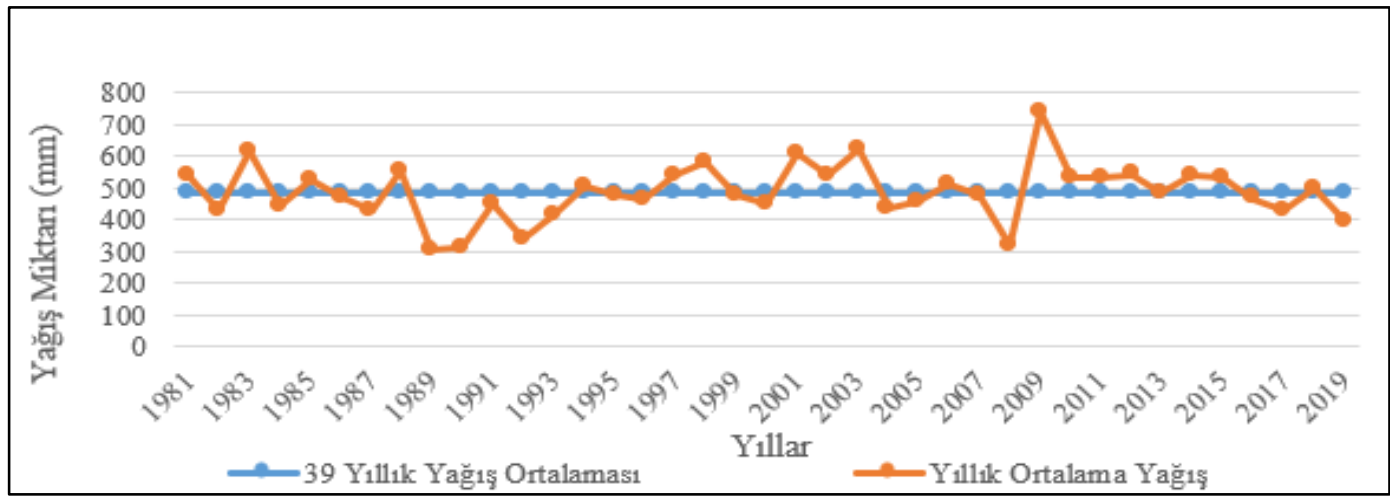

Şekil 3. Salda Gölü Havzası uzun dönem (1981-2019 yılları arası) yıllık ortalama yağış değerleri

MGM verilerinden elde edilerek üretilen, Salda Gölü Havzası'na ait 1981-2019 yılları arasındaki uzun dönem ortalama yağış değerlerinin mevsimsel dağııımı ise Şekil 4 'te verilmiştir. Şekiller incelendiğinde; mevsimsel yağış ortalamaları grafiğinde de düzensiz rejimler görülmektedir. Mevsimsel olarak ortalama yağışın en fazla olduğu mevsim, 190,4 mm ile kış mevsimidir. Kış mevsimini sırasıyla; $140,5 \mathrm{~mm}$ ile ilkbahar, 99,6 $\mathrm{mm}$ ile sonbahar ve $57,6 \mathrm{~mm}$ ile yaz mevsimi takip etmektedir. 39 yıllık süreçte, kış ayları içerisinde en fazla yağışın olduğu yıl or- talama $406 \mathrm{~mm}$ ile 2009 yılı, en düşük olduğu yıl ortalama 52,6 mm ile 2008 yılıdır. İlkbahar ayları içerisinde yağışın en fazla olduğu yıl ortalama 236,3 mm ile 2003 yılı iken, en düşük olduğu yıl ortalama 66,2 mm ile 1986 yılıdır. Yaz mevsimi içerisinde en fazla yağışın olduğu yıl ortalama 145,2 mm ile 2018 yılı iken en az yağış alan yıl $13,5 \mathrm{~mm}$ ile 1993 yılıdır. Sonbahar mevsimi içerisinde en fazla yağış alan yıl ortalama 172,8 mm ile 2007 yılı iken en az yağış alan yıl 34,1 mm ile 1999 yılıdır.

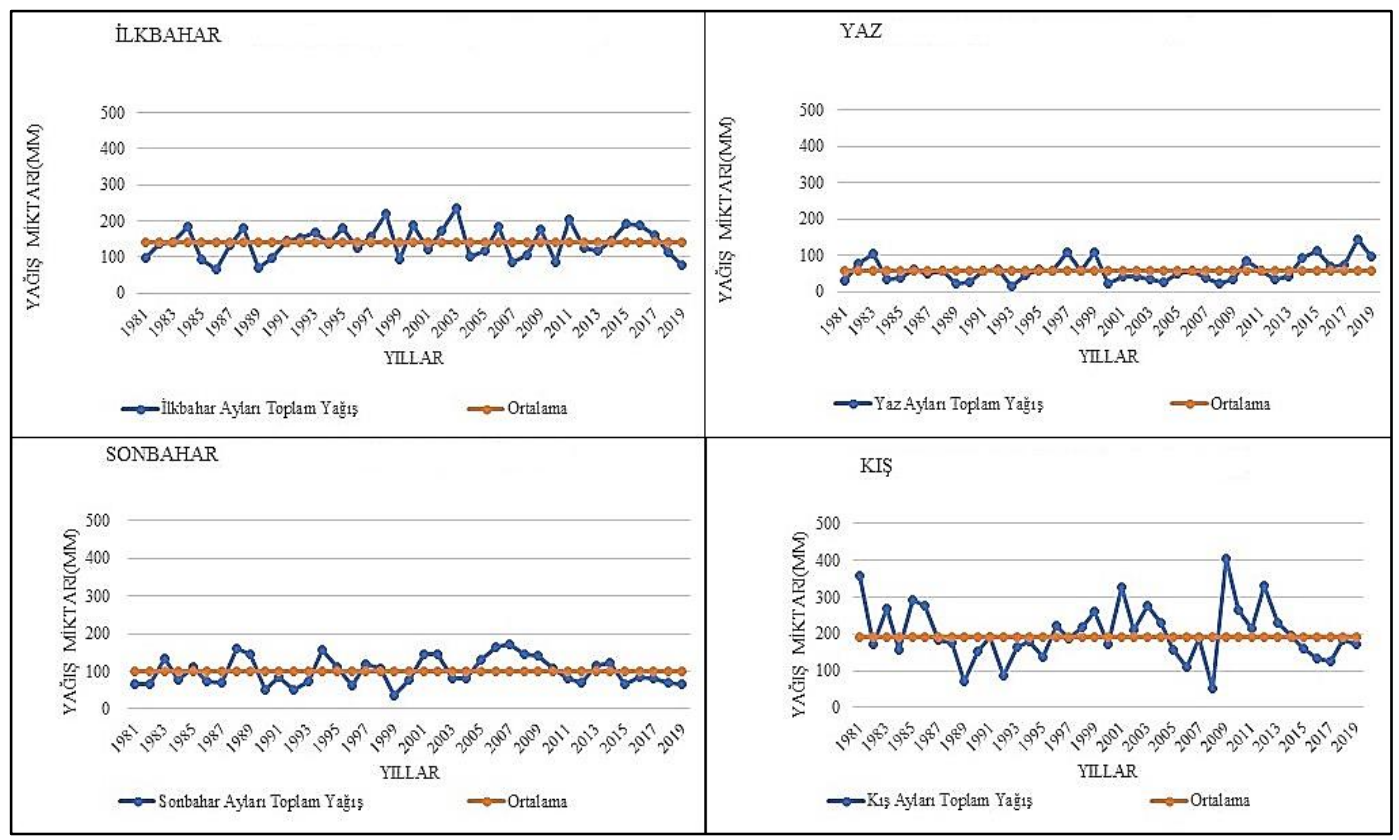

Şekil 4. Salda Gölü Havzası uzun dönem (1981-2019 yılları arası) ortalama yağış değerlerinin mevsimsel dağılımı

MGM verilerine göre Salda Gölü Havzası'na ait 19812019 yılları arasındaki uzun dönem ortalama yağışın aylara göre dağılımı Tablo 1'de yer almaktadır. Tablo 1 incelendiğinde; 1981-2019 yılları arasındaki en yağışlı ay $69,7 \mathrm{~mm}$ ile Aralık ayı iken, en kurak ay 13,6 mm ile
Ağustos ayı olduğu görülmektedir. Mevsim geçişlerindeki yağış farkları, alanda karasal iklimin hakim sürdüğünü desteklemektedir. Genel ortalamaya bakıldığında, yaz aylarının oldukça az yağışlı geçtiği görülmektedir. 
Tablo 1. Salda Gölü Havzası uzun dönem ortalama yağışın $(\mathrm{mm})$ aylara göre dağılımı

\section{Yöntem}

\begin{tabular}{c|ccccc}
\multicolumn{1}{c}{ Aylar } & $\begin{array}{c}\text { ilkba- } \\
\text { har }\end{array}$ & Yaz & $\begin{array}{c}\text { Sonba- } \\
\text { har }\end{array}$ & Kış & $\begin{array}{c}\text { Top- } \\
\text { lam }\end{array}$ \\
\hline $\begin{array}{c}\text { Ocak } \\
\text { Şubat }\end{array}$ & & & & 67,9 & \\
Mart & 51,6 & & & 52,8 & \\
Nisan & 47,0 & & & & \\
Mayıs & 41,9 & & & & \\
Haziran & & 28,6 & & & \\
Temmuz & & 15,4 & & & \\
Ağustos & & 13,6 & & & \\
Eylül & & & 13,9 & & \\
$\begin{array}{c}\text { Ekim } \\
\text { Kasım }\end{array}$ & & & 32,4 & & \\
Aralık & & & 53,3 & & \\
Ortalama & 140,5 & 57,6 & 99,6 & 190,4 & $\mathbf{4 8 8 , 1}$
\end{tabular}

Salda Gölü Havzası'nda yapılan kuraklık analizi çalışmasında kuraklığı tanımlamak için SYİ yöntemi kullanımıştır. SYİ yöntemi; McKee ve ark. (1993) tarafından, yağışın zamana bağlı değişimini ve buna bağlı olarak oluşan kuraklık tiplerini takip etme amacıyla geliştirilen bir yöntemdir. Bu yöntem ile farklı iklim özelliklerine sahip bölgelerde kuraklığı tanımlamak için yağış parametresini tek bir sayısal değere çevirmek ve çeşitli periyotlarda değerlendirmek mümkündür. Birbirinden kesin sınırlarla ayırmak mümkün olmamakla birlikte, 1, 3 ve 6 aylık analizler meteorolojik kuraklığı, 9 ve 12 aylık analizler tarımsal kuraklığı, 12 ve 24 aylık analizler ise hidrolojik kuraklığı görmek için kullanılmaktadır (MGM, 2020).

SYİ, belirlenen bir zaman dilimi içinde yağış ortalamaları arasındaki farkın standart sapmaya bölünmesi ile elde edilir (McKee ve ark., 1993):
$\mathrm{SYI}=\frac{\mathrm{X}_{\mathrm{i}}-\mathrm{X}_{\mathrm{i}}^{\text {ort }}}{\sigma}$

Eşitlikte;

$X_{i}$ : Herhangi bir zamandaki yağış miktarını, $X_{i}^{\text {ort: }}$ Serinin ortalamasını,

$\sigma$ : Serinin standart sapmasını ifade etmektedir.

Bu yöntemde SYİ'nin negatif değer vermesi ile başlayan kurak periyot, SYI'nin pozitif değere dönüşmesi ile bitmektedir. SYl'nin negatif olduğu dönemler kurak dönem olarak değerlendirilmekte, buna karşın pozitif olduğu dönemler ise yağışlı dönem olarak değerlendirilmektedir (Tablo 2) (McKee ve ark., 1993).

Tablo 2. SYİ yöntemine göre Kuraklık İndeksi Sınıflandırması (McKee ve ark., 1993)

\begin{tabular}{l|l} 
Syi Değerleri & Kuraklık Sınıflandırması \\
\hline $2.0>$ SYI & Çok şiddetli yağışlı \\
$1.5<S Y I \leq 2.0$ & Çok yağışlı \\
$1.0<S Y I \leq 1.5$ & Orta şiddetli yağışlı \\
$0<S Y I \leq 1.0$ & Normal \\
$-1.0<S Y I \leq 0$ & Normale yakın kuraklık \\
$-1.5<S Y I \leq-1.0$ & Orta şiddetli kuraklık \\
$2.0<$ SYI $\leq-1.5$ & Şiddetli kuraklık \\
$-2.0 \leq S Y I$ & Çok şiddetli kuraklık
\end{tabular}


SYì yönteminde doğru bir analiz için en az 30 yıllık yağış veri seti gerekmektedir. Salda Gölü'nün bağlı olduğu Burdur ilinde 25 adet Meteoroloji istasyonu bulunmaktadır. Buna karşın çalışma alanı havzası içerisinde ve yakın çevresinde dört adet istasyon mevcuttur. Bunlar; Yeşilova Meteoroloji İstasyonu, Yeşilova/Salda Kayak Merkezi Meteoroloji İstasyonu, Yeşilova/Bayındır Köyü Meteoroloji İstasyonu ve Yeşilova/Harmanlı Köyü Meteoroloji İstasyonu'dur. Bu istasyonlardan uzun dönem yağışlara ait en net veriler 18113 kodlu Yeşilova meteoroloji istasyonuna aittir. Ankara Meteoroloji Genel Müdürlüğü uzmanları ile yapılan görüşmeler sonucunda analiz için Yeşilova Meteoroloji İstasyonuna ait 1981-2019 yılları arasındaki 39 yıllık alansal yağış verilerinin kullanılması uygun görülmüştür.

Çalışmada, Meteoroloji Genel Müdürlüğü'nden alınan aylık yağış verileri öncelikle "MS Excel" yazılımı ile istasyon-yıl bazında düzenlenmiştir. Daha sonra, "SPI generator" (URL-1) bilgisayar yazılımı yardımıyla ham yağış verileri gama dağılımına uydurulmuş ve 1981-2019 yılları arasında (39 yıl) 1-3-6-12 ve 24 aylık SYİ değerleri hesaplanmıştır. Hesaplanan SYI değerleri kuraklık indeksi sınıflarına göre ayrılarak havzadaki meteorolojik, hidrolojik ve tarımsal kuraklık durumları değerlendirilmiştir.

\section{BULGULAR VE TARTIŞMA}

\section{SYí Zaman Serileri}

\section{1 (Bir) Aylık SYí Zaman Serileri}

Yapılan SYİ analizi sonucuna göre Salda Gölü Havzası 1 aylık SYi zaman serileri grafiği Şekil 5'te verilmiştir. Alanda en büyük kuraklık, 1984 yılı Ekim ayında gözlenmiştir. Gözlenen kuraklığın SYİ değeri “-3,37" dir. Toplamda 17 ayda aşırı kuraklık gözlenmiştir. En uzun kuraklık aralığı Ocak 1989 ile Ekim 1989 arasındaki 9 aylık zaman diliminde yaşanmıştır. Alanda gözlenen en şiddetli kuraklık aralığı Ocak 1989 ile Ekim 1989 arasında yaşanan kuraklıktır. Alanda, son 10 yılda uzun bir kuraklık dönemi yaşanmamıştır.

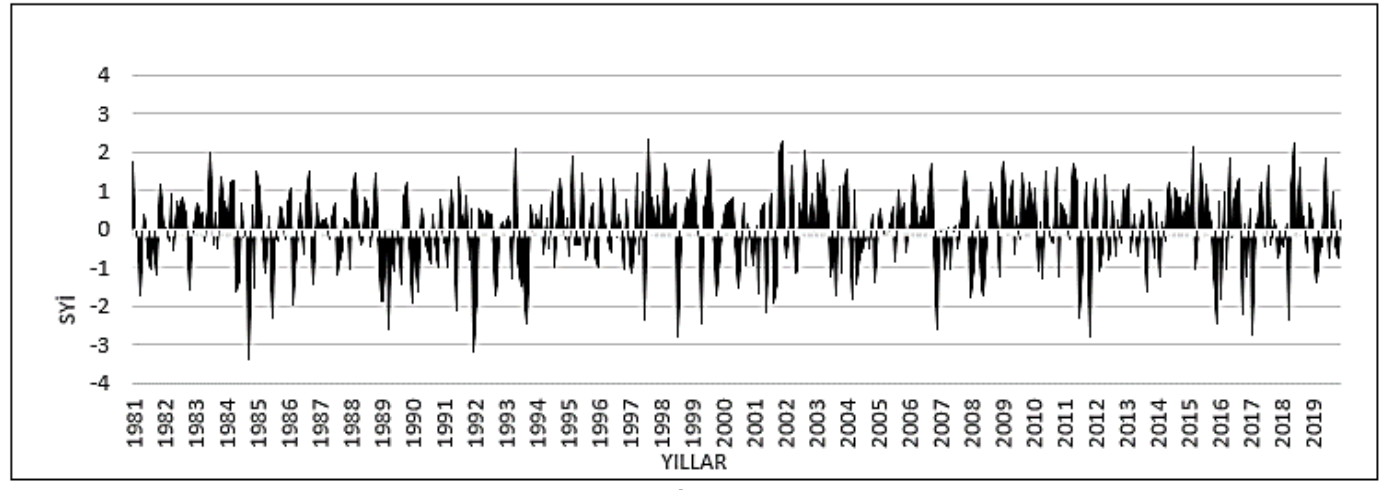

Şekil 5. Bir aylık SYí zaman serileri grafiği

\section{3 (Üç) Aylık SYì Zaman Serileri}

Yapılan SYİ analizi sonucuna göre Salda Gölü Havzası 3 aylık SYI zaman serileri grafiği Şekil 6'da verilmiştir. En büyük kuraklık 1989 yılı Haziran ayında yaşanmıştır. Kuraklığın SYİ değeri “-3,02" dir. Toplamda 14 ayda aşırı kuraklık gözlenmiştir. Alandaki en uzun kuraklık dönemi
Ocak 1990 ile Mayıs 1991 arasındaki 16 aylık zaman diliminde yaşanmıştır. En şiddetli kuraklık aralığı, Ocak 1989 ile Kasım 1989 arasında yaşanmıştır. Alanda, son 10 yılda gözlenen kuraklıklar; Kasım 2007 ile Mayıs 2008 arasında 7 ay süren kuraklıktır. 


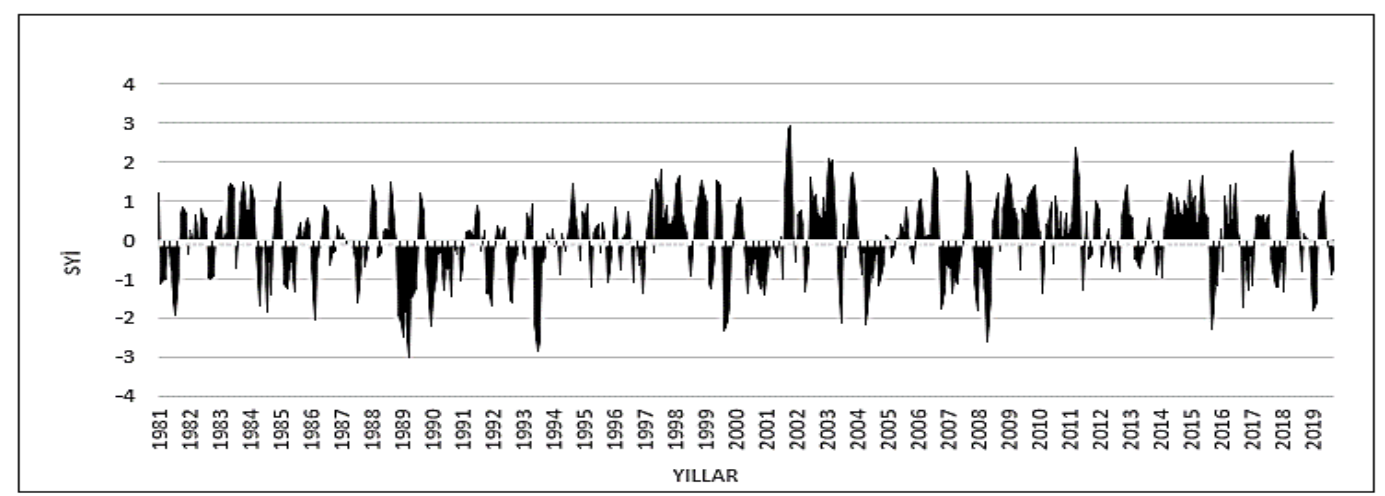

Şekil 6. Üç aylık SYi zaman serileri grafiği

\section{6 (Altı) Aylık SYí Zaman Serileri}

Yapılan SYİ analizi sonucuna göre Salda Gölü Havzası 6 aylık SYi zaman serileri grafiği Şekil 7'de verilmiştir. En büyük kuraklık 1989 yılı Haziran ayında yaşanmıştır. Kuraklığın SYİ değeri "-3,28” dir. Toplamda 9 ayda aşırı kuraklık gözlenmiştir. En uzun kuraklık dönemi Aralık 1990 ile Mayıs 1991 arasındaki 16 aylık zaman diliminde yaşanmıştır. En şiddetli kuraklık dönemi aralığı Ocak
1989 ile Kasım 1989 arasında 10 ay sürmüştür. Son 10 yılda gözlenen kuraklıklar; Aralık 2013 ile Haziran 2014 arasında 6 ay süren, Aralık 2015 ile Haziran 2016 arasında 6 ay süren, Aralık 2016 ile Ağustos 2017 arasında 8 ay süren, Kasım 2017 ile Haziran 2018 arasında 7 ay süren ve Şubat 2019 ile Eylül 2019 arasında 7 ay süren kuraklıklardır.

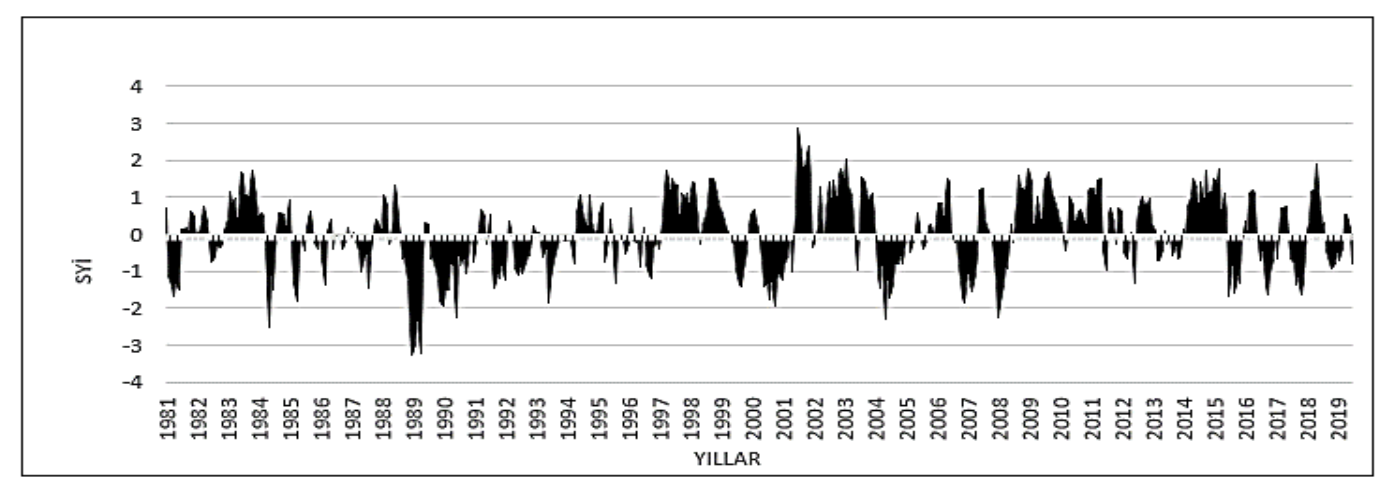

Şekil 7. Altı aylık SYì zaman serileri grafiği

\section{2 (On iki) Aylık SYi Zaman Serileri}

Yapılan SYİ analizi sonucuna göre Salda Gölü Havzası 12 aylık SYİ zaman serileri grafiği Şekil 8'de verilmiştir. En büyük kuraklık 1990 yılı Kasım ayında yaşanmıştır. Görülen kuraklığın SYì değeri "-2,9" dur. Toplamda 7 ayda aşırı kuraklık gözlenmiştir. En uzun kuraklık dö- nemi Şubat 1989 ile Ekim 1994 arasında 68 ay sürmüştür. En şiddetli kuraklık, Şubat 1989 ile Ekim 1994 arasında görülmüştür. Son 10 yılda gözlenen kuraklıklar; Ocak 2014 ile Eylül 2014 arasında 8 ay süren, Şubat 2016 ile Aralık 2018 arasında 34 ay süren ve Mayıs 2019 ile Ocak 2020 arasında 8 ay süren kuraklıklardır. 


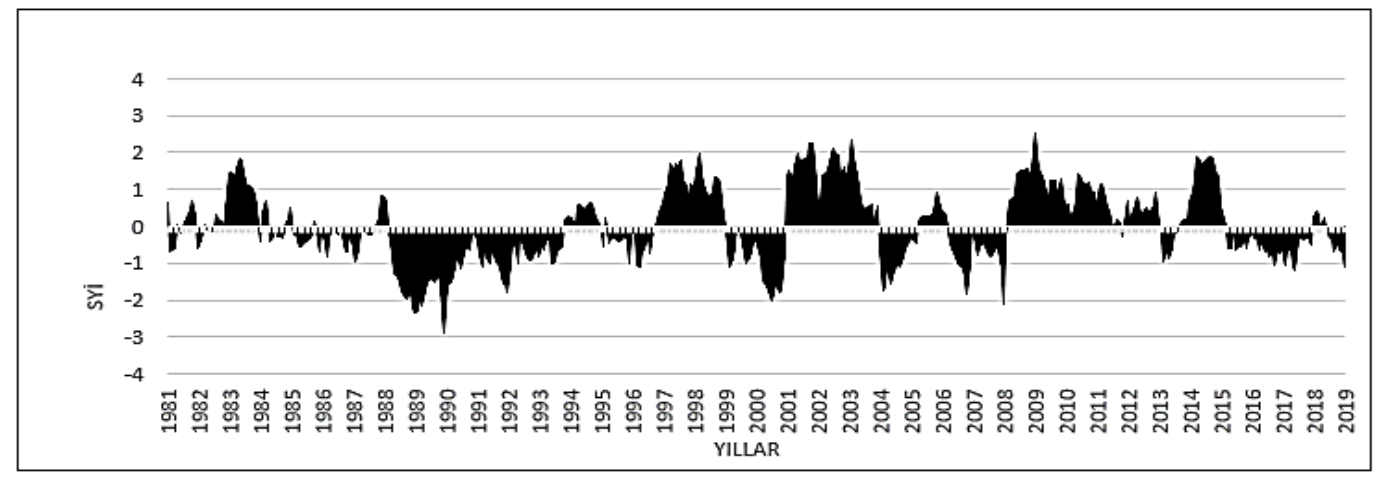

Şekil 8. On iki aylık SYì zaman serileri grafiği

\section{4 (Yirmi dört) Aylık SYí Zaman Serileri}

Yapılan SYI analizi sonucuna göre Salda Gölü Havzası 24 aylık SYİ zaman serileri grafiği Şekil 9'da verilmiştir. En büyük kuraklık 1990 yılı Kasım ve Aralık aylarında görülmüştür. Görülen kuraklığın SYİ değeri “-3,19” dur. Toplamda 9 ayda çok şiddetli kuraklık gözlenmiştir. En uzun kuraklık dönemi; Ocak 1989 ile Mart 1995 arasında 74 ay sürmüştür. En şiddetli kuraklık dönemi, Ocak 1989 ile Mart 1995 arasındadır. Son 10 yılda gözlenen kuraklıklar; Ocak 2014 ile Haziran 2014 arasında 5 ay süren ve Şubat 2017 ile Ocak 2020 arasında 35 ay süren kuraklıklardır.

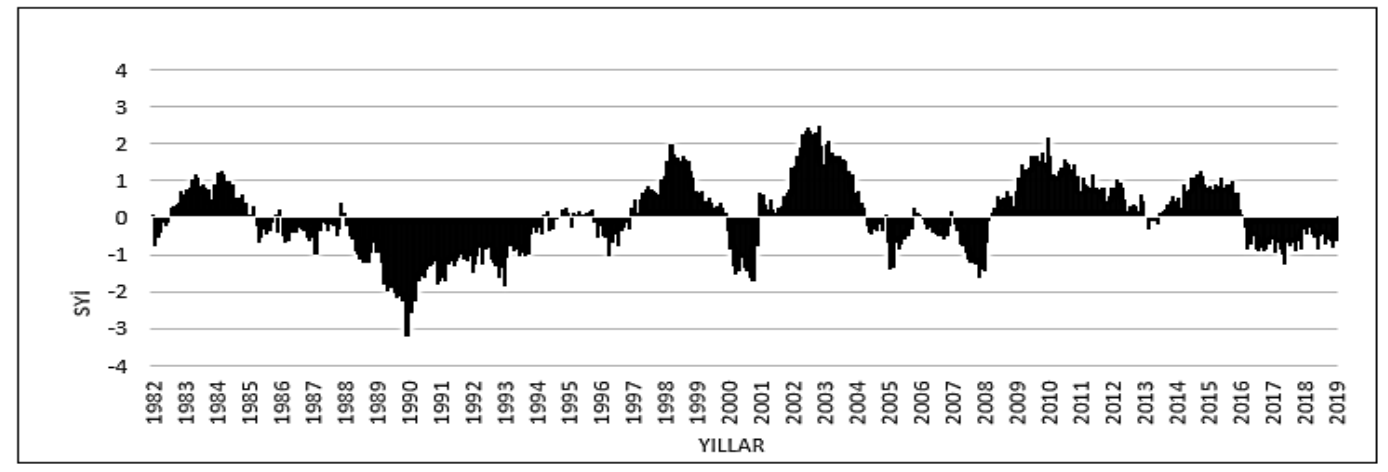

Şekil 9. Yirmi dört aylık SYì zaman serileri grafiği

\section{SYí Sonuçlarına Göre Kuraklık Sınıfları}

Salda Gölü Havzası için yapılan kuraklık analizi sonucunda, tüm SYİ değerlerine göre en uzun kurak dönemler, en şiddetli kurak dönemler, toplam çok şiddetli kurak ay sayısı, en şiddetli kurak aylar, en yüksek SYİ değerleri ve son 10 yılda gözlenen kuraklıklar Tablo 3'te verilmiştir. Tablo incelendiğinde, en şiddetli kuraklığın 5 SYI modelinde de 1989 yılını kapsadığı görülmektedir. 1989 yılının $303.1 \mathrm{~mm}$ ile 1987-2019 yılları arasında en az yağış alan yıl olduğu, alandaki yıllık ortalama yağış miktarları irdelendiğinde ortaya çıkmaktadır. Benzer şekilde SYì tiplerine göre en şiddetli kuraklıklara bakıldığında, hemen hemen tamamının 1989-1990 yılları arasında olduğu göze çarpmaktadır. En şiddetli kuraklık ise SYI 1 değerine göre Ekim 1984 yılında meydana gelmiştir. Kuraklık dönemleri incelendiğinde, SYI aralıklarının arttıkça kurak ay sayısının fazlalaştığı görülmektedir. En uzun süren kuraklık periyodu, SYİ 24'e göre 1989-1995 arasındaki 74 aydır. Bunun aksine toplam çok şiddetli kurak ay sayısı SYì 1'de en fazla görülmüştür.

Son 10 yılda yaşanan kuraklıklar incelendiğinde; SYI 3'e göre 7 ayda, SYI 6'ya göre 34 ayda, SYI 12'ye göre 50 ayda ve SYİ 24'e göre 40 ayda alanda normale yakın ve orta şiddette kuraklık olduğu tespit edilmiştir. Özellikle SYi 6, SYI 12 ve SYI 24 sonuçlarına göre bu aralıkların benzer zaman dilimlerinde olduğu görülmektedir. 
Standartlaştırılmış Yağış İndeksi Yöntemi Kullanılarak Salda Gölü Havzası Kuraklık Analizi Üzerine Bir Araştırma

Tablo 3. "1-3-6-12-24" aylık SYİ zaman serileri grafiği analiz tablosu

\begin{tabular}{|c|c|c|c|c|c|}
\hline & $\begin{array}{l}\text { EN UZUN KURAK } \\
\text { DÖNEM }\end{array}$ & $\begin{array}{l}\text { EN ŞiDDETLİ KU- } \\
\text { RAK DÖNEM }\end{array}$ & $\begin{array}{l}\text { TOPLAM ÇOK } \\
\text { ŞİDDTLI KU- } \\
\text { RAK AY SAYISI }\end{array}$ & $\begin{array}{c}\text { EN Şİ- } \\
\text { DETLİ } \\
\text { KURAK } \\
\text { AY }\end{array}$ & $\begin{array}{l}\text { MAX } \\
\text { SYi(-) }\end{array}$ \\
\hline SYì1 & $\begin{array}{l}\text { Ocak 1989-Ekim } 1989 \\
\text { (9 Ay) }\end{array}$ & $\begin{array}{l}\text { Ocak 1989-Ekim } \\
1989 \text { (9 Ay) }\end{array}$ & 17 & $\begin{array}{l}\text { Ekim } \\
1984\end{array}$ & $-3,37$ \\
\hline SYi3 & $\begin{array}{l}\text { Ocak 1990-Mayıs } \\
1991 \text { (16 Ay) }\end{array}$ & $\begin{array}{l}\text { Ocak 1989-Kasım } \\
1989(10 \mathrm{Ay})\end{array}$ & 14 & $\begin{array}{c}\text { Haziran } \\
1989\end{array}$ & $-3,02$ \\
\hline SYí6 & $\begin{array}{l}\text { Ocak 1990-Mayıs } \\
1991 \text { (16 Ay) }\end{array}$ & $\begin{array}{l}\text { Ocak 1989-Kasım } \\
1989 \text { (10 Ay) }\end{array}$ & 9 & $\begin{array}{c}\text { Haziran } \\
1989\end{array}$ & $-3,28$ \\
\hline SYì12 & $\begin{array}{l}\text { Şubat 1989-Ekim } 1994 \\
\text { (68 Ay) }\end{array}$ & $\begin{array}{l}\text { Şubat } 1989- \\
\text { Ekim1994 (68 Ay) }\end{array}$ & 7 & $\begin{array}{c}\text { Kasım } \\
1990\end{array}$ & $-2,9$ \\
\hline SYi24 & $\begin{array}{l}\text { Ocak 1989-Mart } 1995 \\
\text { (74 Ay) }\end{array}$ & $\begin{array}{l}\text { Ocak 1989-Mart } \\
1995 \text { (74 Ay) }\end{array}$ & 9 & $\begin{array}{c}\text { Kasım- } \\
\text { Aralık } \\
1990\end{array}$ & $-3,19$ \\
\hline
\end{tabular}

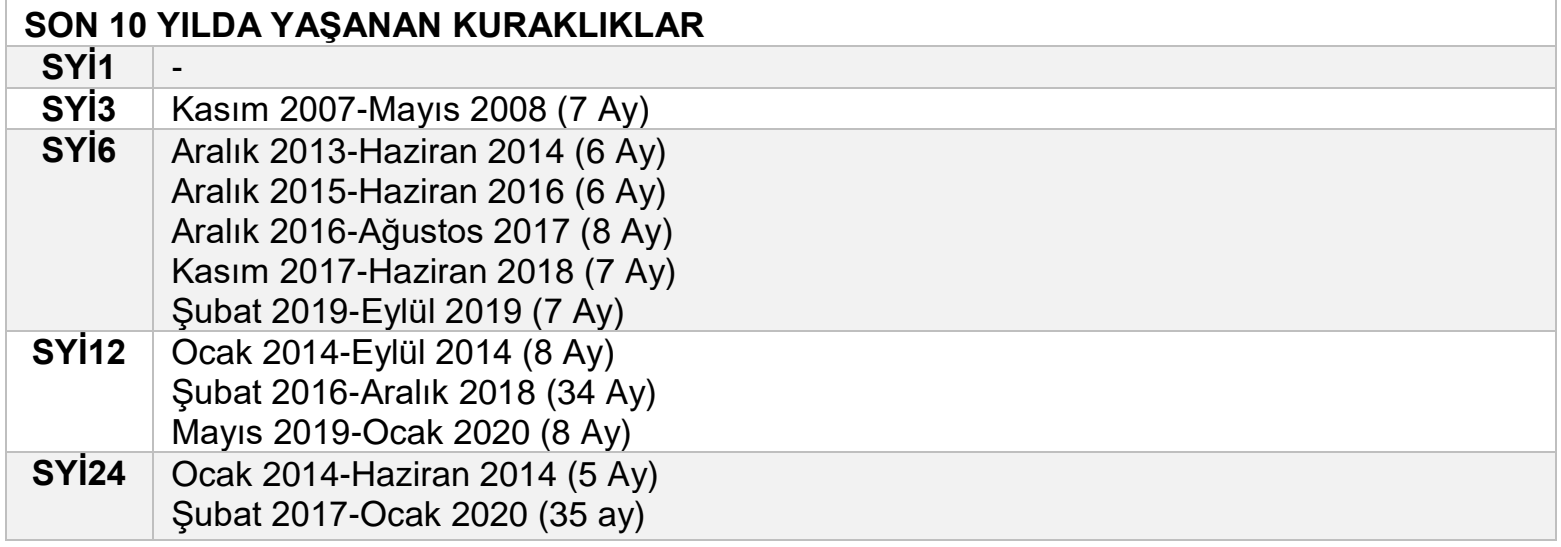

Hesaplanan SYì değerleri, çalışmada verilen Kuraklık Indeksi Sınıflarına göre (Tablo 2) ayrıştırılmış ve yüzdesel dağılım olarak her bir SYİ cinsinden Tablo 4'te verilmiştir. Salda Gölü Havzasında, "Normale Yakın Kuraklık, Orta Şiddetli Kuraklık, Şiddetli Kuraklık ve Çok Şiddetli Kuraklık Oluşum Yüzdeleri” 1 aylık SYİ değerlerine göre sırasıyla $\% 28,84, \% 8,33,4,48,3,63 ; 3$ aylık SYI değerlerine göre sırasıyla \%30,68, \%9,22, \%4,29, \%3; 6 aylık SYI değerlerine göre sırasıyla $\% 32,39, \% 10,79$, $\% 3,88, \% 1,94 ; 12$ aylık SYİ değerlerine göre sırasıyla $\% 40,91, \% 7,43, \% 5,03,1,85,24$ aylık SYİ değerlerine göre $\% 34,15, \% 9,66, \% 4,04, \% 2,02$ olarak belirlenmiştir. Ayrıca alanın genel olarak nemlilik ve kuraklık yüzdelerine bakıldığında 1 aylık SYİ değerine göre $\% 54,72$ nemli, $\% 45,28$ kurak; 3 aylık SYİ değerine göre $\% 52,81$ nemli, \%47,19 kurak; 6 aylık SYİ değerine göre $\% 51,0$ nemli, \%49,0 kurak; 12 aylık SYİ değerine göre \%44,8 nemli, $\% 55,12$ kurak, 24 aylık SYİ değerine göre $\% 50,13$ nemli, \%49,87 kuraktır.

Bu sonuca göre 1 aylık, 3 aylık, 6 aylık, 12 aylık ve 24 aylık SYI değerlerinin yüzde oranları irdelendiğinde, en fazla kuraklık durumunun normal ve normale yakın kuraklık olduğu görülmektedir. Tüm SYI değerlerine göre alanın nemlilik ve kuraklııı durumu birbirine yakındır ve SYí gruplarının kuraklık ortalaması yaklaşık \%49,0 dur. En yüksek kuraklık ortalamasına sahip SYí aralığı $\% 55,12$ ile 12 aylık SYl'dir. 
Standartlaştırılmış Yağış İndeksi Yöntemi Kullanılarak Salda Gölü Havzası Kuraklık Analizi Üzerine Bir Araştırma

Tablo 4. "1,3,6,12,24" Aylık SYİ kuraklık analizi sonuçlarının kuraklık indeksi sınıflarına göre dağııımı

\begin{tabular}{|c|c|c|c|c|c|}
\hline & $\begin{array}{c}1 \text { Aylık } \\
\text { SYí }\end{array}$ & $\begin{array}{c}3 \text { Aylık } \\
\text { SYi }\end{array}$ & $\begin{array}{c}6 \text { Aylık } \\
\text { SYi }\end{array}$ & $\begin{array}{c}12 \text { Aylık } \\
\text { SYi }\end{array}$ & $\begin{array}{c}24 \text { Aylık } \\
\text { SYi }\end{array}$ \\
\hline Çok Şiddetli Yağışıı & 1,28 & 1,5 & 0,86 & 1,09 & 2,02 \\
\hline Çok Yağışıı & 4,05 & 3,43 & 4,53 & 7,43 & 5,39 \\
\hline Orta Şiddetli Yağışıı & 9,61 & 10,51 & 13,6 & 10,06 & 9,43 \\
\hline Normal & 39,78 & 37,37 & 32,01 & 26,3 & 33,29 \\
\hline Normale Yakın Kurak & 28,84 & 30,68 & 32,39 & 40,91 & 34,15 \\
\hline Orta Şiddetli Kurak & 8,33 & 9,22 & 10,79 & 7,43 & 9,66 \\
\hline Şiddetli Kurak & 4,48 & 4,29 & 3,88 & 5,03 & 4,04 \\
\hline Çok Şiddetli Kurak & 3,63 & 3,0 & 1,94 & 1,75 & 2,02 \\
\hline Toplam (\%) & $\% 100$ & $\% 100$ & $\% 100$ & $\% 100$ & $\% 100$ \\
\hline Nemli & $\% 54,72$ & $\% 52,81$ & $\% 51,0$ & $\% 44,8$ & 50,13 \\
\hline Kurak & $\% 45,28$ & $\% 47,19$ & $\% 49,0$ & $\% 55,12$ & 49,87 \\
\hline
\end{tabular}

Yapılan kuraklık analizi literatürle karşılaştırıldığında, bulunan değerlerin daha önce yapılmış olan diğer çalışmalarla benzerlik gösterdiği görülmektedir. Türkeş ve Erlat (2005) tarafından yapılan çalışmada, Türkiye genelinde 1989-1990 yıllarının kurak yıllar olduğu ifade edilmiştir. Dinç ve ark. (2016) tarafından yapılan çalışmada; Demre, Elmalı, Finike, Gazipaşa, Korkuteli ve Manavgat meteoroloji istasyonlarına ait 1970-2014 yılları arasındaki uzun süreli yağış verileri kullanılarak, meteorolojik kuraklık analizi yapılmıştır. SYİ değerleri eğiliminin normale yakın kuraklık aralığında olduğu hesaplanmış ve mevsimsel olarak kuraklığın yaz aylarında olduğu kadar kış aylarında da olabileceğini belirtilmiştir. Aksever (2019) tarafından yapılan çalışmada, Kaklık ovasında (Honaz-Denizli) SYİ yöntemi ile 1975-2018 yılları arasında 44 yıllık kuraklık analizi yapılmıştır. 12 aylık SYİ değerlerine göre; 44 yıl süresince toplam 13 ay "çok kurak" kategorisinde gözlemleme sonucuna varılmıştır. Arslan ve ark. (2016) tarafından yapılan çalışmada, Kızılırmak Havzası'nda 1973-2013 yılları arasındaki kuraklıklar 1,3,6,9,12 aylık SYi analizleri yapılarak hesaplanmıştır. Geçmişteki kuraklıklar ile karşılaştırıldığında havzada meydana gelen son kuraklıkların sürelerinde önemli artışlar tespit edilmiştir. Uçar ve ark. (2019) tarafından yapılan çalışmada, Isparta ilinde 6 istasyona ait yağış verileri yardımıyla SYI metodu kullanılarak kuraklık analizi yapılmıştır. Analiz yapılan 32 yıllık periyot değerlendirilmiş ve değerlendirme sonucunda istasyonların yağış değerlerinde bir azalma eğilimi olmadığı tespit edilmiştir.

\section{SONUÇLAR}

Yapılan analiz sonuçları değerlendirildiğinde; alanda en şiddetli ve en uzun süreli kuraklıkların, 1989-1995 yılları arasında yaşandığı, en kurak mevsimin yaz, en yağışıı mevsimin kış mevsimi olduğu ortaya çıkmıştır. Tüm zamanlar değerlendirildiğinde, SYİ değerleri arasında büyük dalgalanmalar olmamakla birlikte SYİ eğiliminin daha çok "Normale Yakın" $(-1.0<S Y I \leq 0)$ kuraklık riskine yakın olduğu ve özellikle son 10 yılda yaşanan kuraklıklar değerlendirildiğinde alanda her zaman Normale Yakın Kuraklığın olabileceği düşünülmektedir.

Zaman serileri incelendiğinde, kuraklık rejiminin tüm SYI aralıkları için dalgalanmalı olduğu görülürken, bu durum alandaki yağış rejiminin de düzensiz olduğunu ve kış aylarında da kuraklığın olabileceğini göstermektedir. Analiz sonuçlarına göre, alanda kış yağışlarının önemli olduğu tespit edilmiştir. En yağışlı ve en kurak aylar ve mevsimler incelendiğinde, tipik karasal iklim belirtileri görülmektedir. Meteorolojik, tarımsal ve hidrolojik açıdan kuraklık değerlendirildiğinde; 3 tip kuraklığın da alanda görülme riskinin bulunduğu, SYl12 ve SYì24 analiz sonuçlarının yüzdesel oranlarına göre tarımsal ve hidrolojik kuraklık riskinin daha yüksek olduğu görülmektedir.

Kuraklıkla mücadelede, öncelikli olarak bütüncül ve geleceği iyi kurgulayan senaryoların oluşturulması gerekmektedir. Bu senaryoların içerisinde; sosyokültürel yaşam kalitesi, ürün verimliliği, su tasarrufu, endüstriyel faaliyetlerin etkilerinin en aza indirilmesi gibi kavramlar bir arada ve birbirleriyle bağlantılı olarak ele alınmalıdır. Toplumsal bilincin önemli olduğu unutulmamalı ve bu yönde eylemlerin gerçekleşmesi sağlanmalıdır. Sadece halk olarak değil, uzmanların da bu konuda çalışmalarının artması için teşvik edilmesi gerekmektedir.

Kuraklığın ekosistemler üzerinde ciddi riskler oluşturduğu düşünüldüğünde, Salda Gölü Havzası'nda stratejik olarak büyük öneme sahip olan su kaynaklarının etkin kullanımının sağlanması gerekmektedir. Yetkili kurum 
ve kuruluşlar tarafından havzadaki yer altı ve yer üstü sularının etkin ve dengeli kullanımını sağlayacak su yönetim planları oluşturulmalıdır. Ayrıca havzadaki su depolama alanları doğal yollarla artırılmalı, sondaj kuyuları ve sulama göletlerinin kullanımları sınırlandırılmalı, tarımsal faaliyetlerde su intiyacı minumum düzeyde tutularak fazla su kullanımının önüne geçilmesi sağlanmalıdır. Aksi takdirde havzadaki kuraklık riskinin gün geçtikçe daha ciddi çevresel sorunlara yol açması kaçınımaz olacaktır. Yapılan kuraklık analizinde, veri yetersizliği nedeniyle tek bir meteoroloji istasyonu üzerinden değerlendirilme yapılmak durumunda kalınmıştır. Bu ve benzeri kuraklık analizi konusunda çalışmaların artırılması ve daha kapsamlı yapılabilmesi için, gerekli kamu ve kuruluşlar tarafından illerdeki meteoroloji istasyon sayılarının artırıması ve düzenli aralıklarla yağış verilerinin kaydedilmesi gerekmektedir. Böylece ülke genelindeki su yönetimi ve kuraklıkla mücadele faaliyetlerinde, hedeflenen tarımsal politikalarda daha net kararlar alınabilecektir.

\section{TEŞEKKÜR}

Bu çalışma, Süleyman Demirel Üniversitesi, ÖYP Koordinatörlüğünce "ÖYP06445-DR-17" nolu proje tarafından desteklenmiştir. Çalışmada, "Salda Gölü (Burdur) Havzası Ekolojik Risk Değerlendirmesi Üzerine Bir Çaışma" isimli doktora tezi verilerinden yararlanılmıştır.

\section{KAYNAKLAR}

Aksever, F. (2019). Standartlaştırılmış Yağış İndeksi (SYI) Yöntemi İle Kuraklık Analizi ve Kaklık (Honaz-Denizli) Ovasındaki Yeraltısuyu Değişimi. Mühendislik Bilimleri ve Tasarım Dergisi, 7(1): $152-160$.

Arslan, O., Bilgil, A., Veske, O. (2016). Standart Yağış İndisi Yöntemi ile Kızılırmak Havzası'nın Meteorolojik Kuraklık Analizi. Niğde Üniversitesi Mühendislik Bilimleri Dergisi, 5(2): 188-194.

Çevre ve Şehircilik Bakanlığı (2021). Salda Gölü Özel Çevre Koruma Bölgesi, https://tvk.csb.gov.tr/salda-golu-i-91578 (Erişim Tarihi: 03.04.2021)
Dinç, N., Aydinşakir, K., Işık, M., Büyüktaş, D. (2016). Standartlaştırılmış Yağış İndeksi (SPI) Yöntemi ile Antalya İli Kuraklık Analizi. Derim, 33(2): 279-298.

Dracup, J.A., Lee,K.S., Paulson, E.G. (1980). On the Definition of Droughts. Water Resources Research, 16: 297-302.

Kapluhan, E. (2013). Türkiye'de Kuraklık ve Kuraklığın Tarıma Etkisi. Marmara Coğrafya Dergisi, 27: 487-510.

Kültür ve Turizm Bakanlığı (2021). Tarihi Yapılar ve Gezilecek Yerler, https://burdur.ktb.gov.tr/TR-154881/salda-golu.html (Erişim Tarihi: 19.03.2021).

Kesici, E., Kesici, K., Kesici, C. (2018). Salda Gölü Korunan Alanının Sürdürülebilirliği. Doğanın Sesi Dergisi, 1(1): 3-11.

McKee, T.B., Doesken, N.J., Kleist, J. (1993). The Relationship of Drought Frequency and Duration to Time Scales, $8^{\text {th }}$ Conference on Applied Climatology, 17-22 January, 1993, Anaheim, CA, 179-184.

MGM (2020). Ankara Meteoroloji Genel Müdürlüğü Verileri, Ankara.

MGM (2021). Kuraklık Analizi Kuraklık Sınıflandırması, https://www.mgm.gov.tr/veridegerlendirme/kuraklik-analizi.aspx?d=yontemsinif\#sfB (Erişim Tarihi: 04.03.2021).

Orman ve Su İşleri Bakanlığı, (2013). Salda Gölü Sulak Alan Alt Havzası Biyoçeşitlilik Araştırması. Ortadoğu Ormancılık Proje Etüt ve Müşavirlik, 283s, Ankara.

Şaylan, L., Durak, M., Şen, O. (1997). Kuraklık ve Etkileri, Meteorolojik Karakterli Doğal Afetler Sempozyumu, 7-9 Ekim, 1997, Ankara, 433-444.

TMMOB (2020). Türk Mühendis ve Mimarlar Odası Birliği Ziraat Mühendisleri Odası Salda Gölü Raporu, 139s.

Türkeş, M., Erlat, E. (2005). Climatological Responses of Winter Precipitation in Turkey to Variability of the North Atlantic Oscillation During the Period 1930-2001. Theoretical and Applied Climatology, 81(1-2): 45-69.

Uçar, Y., Topçu, E., Demirel, E. (2019). Standartlaştırılmış Yağış İndeksi Yöntemi ile Isparta İli Kuraklık Analizi. Türk Bilim ve Mühendislik Dergisi, 1(1): 5-16.

Yürekli, K., Anlı, A. S., Örs, İ., Karahan, G. (2009). Sakarya Havzası Aylık Akımlarının Kuraklık Analizi, I. Ulusal Kuraklık ve Çölleşme Sempozyumu Bildiriler Kitabı, 16-18 Haziran, 2009, Konya, 779-784.

URL-1 (2020). SPI Generator. https://www.nxp.com/design/development-boards/automotive-development-platforms/mpc56xx-mcu-platforms/spi-generator-spigensoftware:SPIGEN (Erişim tarihi: 20.12.2020).

Wilhite, D.A., Glantz, M.H. (1987). Understanding the Drought Phenomenon: The Role of Definitions. Chapter 2, In: Drought Mitigation Center Faculty Publications, 86: 11-27. 